\title{
Strengthening Human Rights in Global Health Law: Lessons from the COVID-19 Response
}

\section{Global Health Law}

\author{
Judith Bueno de Mesquita, \\ Anuj Kapilashrami, and \\ Benjamin Mason Meier
}

Keywords: Human Rights, Global Health, COVID-19, World Health Organization, United Nations

Human rights are central to global health, yet human rights weaknesses in the COVID-19 response have highlighted both the intrinsic and instrumental importance of strengthening human rights in global health law. Reflecting on human rights limitations in the pandemic, the World Health Assembly (WHA) is just beginning work to improve capacity for global pandemic prevention, preparedness, and response, presenting opportunities to ensure human rights realization in future public health emergencies. It will be crucial in these reforms to strengthen human rights in global health, enabling the World Health Organization (WHO) to support member states in realizing health-related human rights.

This column addresses the need to strengthen human rights in global health, looking to violations of human rights law in the pandemic response to recommend rights-based reforms in global health law. The column opens by examining the fundamental importance of human rights, recognizing the centrality of human rights in global health governance. Notwithstanding the evolution of health-related human rights under international law, the COVID-19 pandemic response has posed sweeping implications for the realization of human rights, with state responses failing to comply with their domestic and international human rights obligations. Raising an imperative to strengthen human rights in global health law, this column presents recommendations to advance health through the United Nations (UN) human rights system, extend human rights in revisions of the International Health Regulations (IHR), and mainstream human rights in WHO governance.

\section{Human Rights Law in Global Health Governance}

Facilitating dignity, well-being, and justice under international law, human rights stand as a central normative framework for global health, offering universal standards by which to frame government responsibilities and facilitate international accountability. With the UN seeking to promote "respect for, and observance of, human rights and fundamental freedoms for all," states have worked within the UN to establish healthrelated human rights under international human rights law, developing a formal legal basis to codify norms and principles for the realization of health care and underlying determinants of health. Human rights law has thus become a foundation to frame infectious disease prevention, detection, and response.

Following from the development of health-related human rights under
Law at Georgetown University Law

Center and Director of the World

Health Organization Center on

National and Global Health Law.

Professor Meier is an Associate

Professor of Global Health Policy at the University of North Carolina at Chapel Hill and a Scholar at the O'Neill Institute for National and Global Health Law. This column will feature timely analyses and perspectives on law, policy, and justice in global health.
Judith Bueno de Mesquita, LL.M., M.A., is Co-Deputy Director of the Human Rights Centre and Lecturer in International Human Rights Law in the School of Law, University of Essex. Anuj Kapilashrami, Ph.D., M.Sc., M.A., is Professor in Global Public Health Policy छं Equity (Gender Eं Intersectionality) at the School of Health E' Social Care, University of Essex, member of the People's Health Movement, and founding Chair of the Migration Health South Asia network. Benjamin Mason Meier, J.D., LL.M., Ph.D., is a Professor of Global Health Policy at the University of North Carolina at Chapel Hill, a Scholar at the O'Neill Institute for National and Global Health Law, and the founding Chair of the American Public Health Association's Human Rights Forum. 
international treaties, the UN has shifted to the implementation of human rights through national governments and global institutions, seeking to mainstream human rights in global health governance. Since the early years of the HIV/AIDS response, which revealed the inextricable linkages between health and human rights, WHO has sought to implement human rights across its policies, programs, and practices. ${ }^{2}$ As the WHA moved to revise the International Health Regulations (IHR) at the turn of the century, it incorporated human rights obligations as central to responding to public health emergencies, with IHR (2005) requiring that implementation "shall be with the full respect for the dignity, human rights and fundamental freedoms of persons."3

Impact of COVID-19 and COVID19 Responses on Human Rights

However, the global response to COVID-19 has weakened these foundations of human rights law in global health, with UN Secretary-General Antonio Guterres decrying "a pandemic of human rights abuses in the wake of COVID-19."4 Highlighting limitations of human rights in global health law, violative pandemic responses have undermined international human rights obligations to realize (1) the rights to health and life (2) human rights that underlie public health, and (3) international assistance and cooperation.

\section{The Rights to Health and Life}

The right to health, codified seminally in the 1966 International Covenant on Economic, Social and Cultural Rights (ICESCR), requires states to take legal and policy measures to respect, protect, and fulfill determinants of health; prevent, treat, and control infectious diseases; and make health services available, accessible, acceptable, and good quality. ${ }^{5}$ Yet, states have neglected these obligations in the pandemic response through failures to establish effective testing, contact tracing, social distancing, isolation, and quarantine policies. ${ }^{6}$ With national health systems weakened by years of fund-

ing cuts in contexts of austerity and structural adjustment, states have struggled to provide treatment, care, and vaccination to all in need in the pandemic response. ${ }^{7}$ These failures to guarantee determinants of health on the basis of equality and non-discrimination have shaped the unequal distribution of infections and deaths in the COVID-19 pandemic, placing increased burdens on vulnerable and marginalized communities.

\section{The global response to COVID-19 has weakened these foundations of human rights law in global health, with UN Secretary-General Antonio Guterres decrying "a pandemic of human rights abuses in the wake of COVID-19." Highlighting limitations of human rights in global health law, violative pandemic responses have undermined international human rights obligations to realize (1) the rights to health and life (2) human rights that underlie public health, and (3) international assistance and cooperation.}

\section{Human Rights that Underlie Public Health}

The 1966 International Covenant on Civil and Political Rights explicitly recognizes an imperative for states to limit or derogate from certain rights where strictly necessary to protect public health. The Siracusa Principles on the Limitation and Derogation Provisions in the International Covenant on Civil and Political Rights (1984) first sought to define the scope of permissible limitations of civil and political rights - where such measures are necessary, proportionate, non-discriminatory, and subject to review. ${ }^{8}$ Properly designed and implemented, such restrictions on specific rights can safeguard rights to life and health through public health measures, including social distancing, surveillance, lockdowns, curfews, isolation, and quarantine. However, emergency responses in many countries have been adopted tous repercussions in ensuring rights to adequate food, education, housing, standards of living, and physical and mental health. ${ }^{10}$

\section{International Assistance and Cooperation}

These human rights obligations must be realized both domestically and through international assistance and cooperation. Building from the 1948 Universal Declaration of Human Rights (UDHR), which recognizes that "everyone is entitled to a social and international order" in which rights and freedoms can be realized, international human rights law has evolved to establish international obligations to support the progressive realization of human rights in states lacking the resources to meet their domestic obligations. ${ }^{11}$ With wide-ranging implications for global health governance, the UN system has repeatedly called for global solidarity 
in the pandemic response. However, many high-income states have failed to comply with their transboundary obligations, enacting nationalist measures that restrict the international flow of essential goods. ${ }^{12}$ This neglect of global health governance in confronting a global health threat has led to devastating COVID-19 inequities and limited vaccine access, as high-income states have blocked waivers of intellectual property rights and failed to adequately fund and supply the COVAX Initiative. ${ }^{13}$

\section{Strengthening Human Rights in Global Health Law and Governance}

Action is needed to strengthen human rights in global health law and governance. Human rights have increasingly come to be seen as a central responsibility of institutions of global health governance. ${ }^{14}$ Recognizing the continuing linkages between human rights and public health, UN agencies have been united in calls for human rights-based responses to COVID-19. Out of the limitations of the COVID19 response, new opportunities are arising to improve compliance with human rights law through (1) emerging guidance on human rights-based approaches (2) reprioritizing human rights in infectious disease control, and (3) building human rights capacity in the WHO.

\section{Emerging Guidance on Human Rights-Based Approaches}

The realization of human rights is necessary both to protect public health and to maintain the core international values that bind the world together. Seeking to incorporate international human rights law in public health practice, institutions within the UN human rights system have issued extensive guidance on rights-based responses to COVID19, providing the building blocks for states and international organizations to implement human rights in legal and policy responses to the pandemic, including in the implementation of global health law. With efforts to update the Siracusa Principles already underway, it will be necessary to align principles of human rights law and global health law in facing future public health threats. ${ }^{15}$

\section{Reprioritizing Human Rights in Infectious Disease Control}

The continuing evolution of global health law, including through anticipated revisions of the IHR and a new pandemic treaty, will create opportunities for enhancing the legal protection of human rights. This opportunity to promote global health security while safeguarding human rights can allow the WHA to codify specific human rights obligations in the context of infectious disease control. As seen in the COVID-19 response, public health emergencies can create scientific uncertainty and demand global solidarity, and it is necessary for global health law to elaborate relevant human rights principles to shape contemporary public health practice. ${ }^{16}$ Drawing from human rights interpretations in the context of COVID-19, revisions of global health law can more robustly incorporate civil, political, economic, social, and cultural rights throughout infectious disease control, guiding states in realizing human rights to support public health and clarifying whether, when, and how to resort to public health measures that may limit human rights.

\section{Building Human Rights Capacity in the WHO}

WHO's high level commitment to human rights, reflected in its Global Programme of Work (2019-23) and robust defense of the right to health in the COVID-19 response, ${ }^{17}$ now demands capacity building efforts to mainstream human rights in WHO governance. Mainstreaming human rights across the Organization (at headquarters, regional, and country levels) will require technical guidance and staff training on rights-based approaches to health, spaces for civil society participation in organizational decisionmaking, and institutional accountability for the progressive realization of the right to health. Through collaboration with the Office of the UN High Commissioner for Human Rights, WHO has recently formalized a Framework of Coop- eration to build capacity for human rights-based approaches in health programming and strengthen consideration of health by the UN human rights system. ${ }^{18}$ This agreement provides a pathway for the WHO to support human rights accountability in the COVID-19 response - which will be critically important as UN treaty bodies resume review processes and the UN Human Rights Council provides oversight through the Universal Periodic Review. ${ }^{19}$

\section{Conclusion}

As the WHA looks to advance human rights in global health, it will be necessary to strengthen human rights in global health law and governance in preparing for future public health emergencies. WHO must continue to take steps to mainstream human rights in global health, expanding its human rights staff to support human rights implementation in WHO policies, programs, and practices. As states prepare for future revisions of global health law - through revisions of the IHR and an independent pandemic treaty - it will be crucial to ensure that global health law reconciles public health imperatives with human rights protections, safeguardinig individual rights and supporting global solidarity. Extending partnerships between global health governance and the UN human rights system, rights-based oversight mechanisms can be developed to hold states accountable for realizing human rights law in responding to public health threats. These reforms provide a path to strengthen human rights in global health law, learning from the COVID-19 response to build back better.

\section{Note}

This column is based upon the human rights background paper that was developed by the co-authors for the Independent Panel on Pandemic Preparedness and Response.

\section{Acknowledgements}

The authors are grateful to Preeyanka Rao for her research assistance in developing this column. 


\section{References}

1. Charter of the United Nations (San Francisco: United Nations, 1945)

2. L. O. Gostin et al., "70 Years of Human Rights in Global Health: Drawing on a Contentious Past to Secure a Hopeful Future," The Lancet 392, no. 10165 (December 22, 2018): 2731-35, available at <https://doi.org/10.1016/ S0140-6736(18)32997-0> (last visited April 27, 2021).

3. L. O. Gostin, R. Habibi, and B. M. Meier, "Has Global Health Law Risen to Meet the COVID-19 Challenge? Revisiting the International Health Regulations to Prepare for Future Threats," Journal of Law, Medicine Eं Ethics 48, no. 2 (2020): 376-381, available at <https:// doi.org/10.1177/1073110520935354> (last visited April 27, 2021).

4. A. Guterres, "The World Faces a Pandemic of Human Rights Abuses in the Wake of Covid-19," The Guardian, February 22, 2021, available at <http:// www.theguardian.com/global-development/2021/feb/22/world-facespandemic-human-rights-abuses-covid19-antonio-guterres> (last visited April 27, 2021).

5. UN General Assembly, International Covenant on Economic, Social and Cultural Rights (New York: United Nations, 1966); UN Committee on Economic, Social and Cultural Rights, General Comment 14 on the Right of Everyone to the Enjoyment of the Highest Attainable Standard of Physical and Mental Health (article 12 of the International Covenant on Economic, Social and Cultural Rights), Geneva: United Nations; 2000, U.N Doc. E/C.12/2000/1.

6. D. P ras et al., "The Right to Health Must Guide Responses to COVID-19," The Lancet 395, no. 10241 (2020): 1888-1890, available at <https://doi. org/10.1016/S0140-6736(20)31255-1> (last visited April 27, 2021).

7. $\quad$ See $\mathrm{P}$ ras et al., supra note 6 .

8. United Nations, UN Commission on Human Rights, The Siracusa Principles on the Limitation and Derogation Provisions in the International Covenant on Civil and Political Rights. Geneva: United Nations; Sept 28, 1984, U.N. Doc. E/CN.4/1985/4

9. S. Sekalala et al., "Health and Human Rights Are Inextricably Linked in the COVID-19 Response," BMJ Global Health 5, no. 9 (September 1, 2020): e003359, available at <https://doi. org/10.1136/bmjgh-2020-003359> (last visited April 27, 2021).

10. A. Kapilashrami et al., The State of the World's Human Rights. (London: Amnesty International, 2021), available at <https://wwre. amnesty.org/download/Documents/ POL1032022021ENGLISH.PDF> (last visited April 27, 2021).

11. UN General Assembly, Universal Declaration of Human Rights (New York United Nations, 1948); UN General Assembly, supra note 5, art. 2.1.

12. UN Committee on Economic and Social and Cultural Rights, "Statement on the Coronavirus Disease (COVID19) Pandemic and Economic, Social and Cultural Rights," April 17, 2020, available at <http://digitallibrary. un.org/record/3856957> (last visited April 27, 2021)

13. L. O. Gostin, S. A. Karim, and B. M. Meier, "Facilitating Access to a COVID-19 Vaccine through Global Health Law," Journal of Law, Medicine छ Ethics 48, no. 3 (2020): 622-626, available at <https://doi. org/10.1177/1073110520958892> (last visited April 27, 2021)

14. L. O. Gostin and B. M. Meier, Human Rights in Global Health: Rights-Based Governance for a Globalizing World (Oxford: Oxford University Press, 2018).

15. R. Habibi et al., "Harmonizing Global Health Law and Human Rights Law to Develop Rights-Based Approaches to Global Health Emergencies," International Commission of Jurists (blog), February 24, 2021, available at <https://www.icj.org/ harmonizing-global-health-law-andhuman-rights-law-to-develop-rightsbased-approaches-to-global-healthemergencies> (last visited April 27, 2021).

16. B. M. Meier, H. E. Huffstetler, and R. Habibi, "Human Rights Must Be Central to the International Health Regulations," Health and Human Rights Journal (blog), August 26, 2020 , available at <https://www.hhrjournal. org/2020/08/human-rights-must-becentral-to-the-international-healthregulations/> (last visited April 27, 2021).

17. World Health Organization, "Addressing Human Rights as Key to the COVID-19 Response," available at $<$ https://www.who.int/publicationsdetail-redirect/addressing-humanrights-as-key-to-the-covid-19-response.> (last visited April 11, 2021).

18. World Health Organization, "Agreement Signed between WHO and UN Human Rights Agency to Advance Work on Health and Human Rights,' WHO (World Health Organization), available at <http://www.who.int/lifecourse/news/who-unhcr-agreementon-health-and-human-rights/en/> (last visited April 11, 2021).

19. J. Bueno de Mesquita et al., "Monitoring the Sustainable Development Goals through Human Rights Accountability Reviews," Bulletin of the World Health Organization 96, no. 9 (2018): 627-633, available at <https://doi. org/10.2471/BLT.17.204412> (last visited April 27, 2021); M. Kothari, "The UN's Universal Periodic Review Must Respond to COVID-19," Blog, OpenGlobalRights, January 26, 2021, available at <https://www.openglobalrights. org/the-un-universal-periodic-reviewmust-respond-to-covid/> (last visited April 27, 2021). 